\title{
The Contribution of Audit Committees in the Reduction of the Liquidity Risk Levels in the Jordanian Commercial Banks
}

\author{
Mohammad Al-Hajaia ${ }^{1}$ \& Firas Hashem ${ }^{1}$ \\ ${ }^{1}$ Accounting Department, Tafilah Technical University, Jordan \\ Correspondence: Firas Hashem, Accounting Department, Tafilah Technical University, Jordan. E-mail: \\ Firashashem@yahoo.com
}

Received: July 2, 2018

doi:10.5539/ijbm.v13n10p192

\begin{abstract}
This study aimed to identify the extent of the audit committees' contribution in the reduction of the liquidity risk levels in the Jordanian commercial banks. The current study also aimed to identify whether there are any statistically significant differences between the extent of the audit committees' contribution in the reduction of the liquidity risk levels in the Jordanian commercial banks that can be attributed to the auditor's years of experience and academic qualification. As for the population of the current study, it consisted of all the internal auditors working in the Jordanian commercial banks. As for the sample, it consisted of forty (40) internal auditors working in Jordanian commercial banks.
\end{abstract}

\section{The Researcher has concluded the following results:}

1. Audit committees participate in reducing the liquidity risk levels in the Jordanian commercial banks.

2. There are statistically significant differences between the extent of the audit committees' contribution in the reducing the liquidity risk levels in the Jordanian commercial banks which can be attributed to the auditor's experience.

3. There are no statistically significant differences between the extent of the audit committees' contribution in the reduction of the liquidity risk levels in the Jordanian commercial banks which can be attributed to the auditor's academic qualification.

\section{The researcher has suggested the following recommendations:}

1. The researcher of the current study recommended providing more attention to developing the work performance of internal auditors in the Jordanian commercial banks. That shall be done in the aim of raising the accuracy and reliability of the financial statements they make.

2. The researcher of the current study recommended encouraging internal auditors to comply with the principles of accuracy and reliability in their financial statements in Jordanian commercial banks. The researcher also recommended promoting this to be their dominant way of thinking

3. The researcher of the current study recommended developing the internal auditors' performance in using the advanced information systems. That shall be done in the aim of raising the accuracy and reliability of their financial statements to reduce the liquidity risk levels.

4. The researcher of the current study recommended conducting more studies about the same matter with applying them on other sectors.

Keywords: auditing, audit committees, liquidity risk, commercial banks

\section{Introduction}

Banking risk management is considered one of the most significant topics which bankers have been giving much attention in all over the world. The significance of such management has been increasing after experiencing successive financial and banking crises, especially after the financial crisis in Mexico at the end of the year 1994. This Mexican crisis was followed by financial crises in Southeast Asian countries and Brazil. Such crises also include the financial crisis which was experienced recently by the US banks and global economy. The latter crisis resulted in the bankruptcy of major US banks. It was concluded that the most significant reason behind the 
occurrence of such banking crises is the increasing number of banking risk levels that have been facing banks. Other significant reasons also include not managing banking risks efficiently and having a poor internal and external control in banks.

Thus, the significance of internal auditing has been increasing in banks. That is because such type of auditing has a major impact upon the work performance levels at banks. Such type of auditing aims at maximizing the profitability of shareholders and ensuring the continuation of business operations. Such type of auditing also aims at preserving the market price of shares and customers' deposits in the light of having high levels of risk. The current study also aimed to identify the extent of audit committees' contribution in reducing the liquidity risk levels in the Jordanian commercial banks.

\subsection{Statement of the Problem}

Commercial banks have been facing various types of risks. However, the most significant type of risks facing banks is the liquidity risk levels. Thus, that requires coming up with solutions that can reduce the latter risk levels. However, it should be noted that audit committees are considered one of those solutions.

Hence, the problem of the current study can be seen through seeking to provide answers for the following questions:

1) To what extent do the audit committees participate in reducing the liquidity risk levels in the Jordanian commercial banks?

2) Are there any statistically significant differences between the extent of audit committees' contribution in reducing the liquidity risk levels in the Jordanian commercial banks which can be attributed to the auditor's years of experience or academic qualification?

\subsection{Significance of the Study}

The significance of the current study can be seen through tackling a significant issue represented in the extent of the audit committees' contribution in reducing the liquidity risk levels in the Jordanian commercial banks. The significance of the current study is also represented in investigating this issue in one of the most significant economic sectors in Jordan which is the banking sector.

\subsection{Objectives of the Study}

The current study aims at achieving the following objectives:

1) Identifying the extent of the audit committees' contribution in reducing the liquidity risk levels in the Jordanian commercial banks

2) Identifying whether there are any statistically significant differences between the extent of the audit committees' contribution in reducing the liquidity risk levels in the Jordanian commercial banks which can be attributed to the auditor's years of experience or academic qualification

\section{Review of Literature}

Al-Sartawi et al. (2013) conducted a study titled "The impact of the audit committees in the Jordanian public joint stock companies on the efficiency of profit management".

The study of Al-Sartawi et al. (2013) aimed to identify the extent of the Jordanian public joint stock companies' application for the institutional governance instructions of audit committees - that are stated in the Jordanian laws and regulations - when managing the company's profits. The study's population consisted of fifty (50) industrial public joint stock companies that were listed in Amman Stock Exchange during the six years that preceded the global financial crisis (i.e.2001 - 2006). In order to achieve the study's objectives, the researchers used a group of statistical methods that are considered appropriate. Their study concluded that the industrial public joint stock companies in Jordan are committed to the application of the institutional governance instructions of audit committees as they are stated in the Jordanian laws and regulations.

There were statistical analysis made to examine the characteristics of audit committees. Such analysis have showed that the size of the audit committee and its number of meeting it hold and the years of financial experience of its member have an impact on the efficiency of the company's profit management. However, it was found out that the independency of the audit committee's members has an impact on the efficiency of the company's profit management. As for the ownership ratio of the audit committee's members to the company's shares, it had a major impact on raising the company's efficiency in managing its profits.

Al-Soos (2012) conducted a study titled "the extent of the audit committees' efficiency in supporting the internal and external audit mechanisms" 
The study of Al-Soos (2012) aimed to identify the extent of audit committees' efficiency in supporting the internal and external audit mechanisms in Palestinian banks. The study was conducted the perspective of internal and external auditors and inspectors sent by the Palestine Monetary Authority (PMA) to these banks. Al-Soos (2012) designed a questionnaire to collect the required data from the study's respondents that consisted of (57) internal external auditors,(25)external auditors and (20) inspectors sent by the Palestine Monetary Authority (PMA).

The study of Al-Soos (2012) concluded several results. For instance, it was concluded that the audit committees' members possess the characteristics that are required to enable them to practice their roles efficiently in supporting the internal and external auditing departments. It was also concluded that the audit committees in the Palestinian banks are committed to implementing the specified tasks and responsibilities assigned to them in accordance with the regulations and instructions. It was also concluded that the audit committees in the Palestinian banks follow certain working mechanisms when performing the tasks assigned to them.

The study of Al-Soos (2012) also suggested several recommendations. For instance, he recommended identifying the concepts related to independency and their meanings. He also recommended establishing clear and specific terms and requirements for independency by the Palestine Monetary Authority (PMA). He also recommended including a report about the tasks performed by the audit committee throughout the year in the final report of the financial statements published by the bank at the end of the fiscal year.

Al-Shawawra\& Al-Hamaydeh (2010) conducted a study titled "the role of the internal audit units in improving the efficiency of the audit committees emerging from the board of directors in the Jordanian public joint stock companies (A field study)

The study of Al-Shawawra \& Al-Hamaydeh (2010) aimed to investigate and analyze the role of the internal audit units in improving the efficiency of the audit committees emerging from the board of directors in the Jordanian public joint stock companies. It should be noted that having an efficient internal auditing shall strengthen the role of the audit committees. Furthermore, having an efficient internal auditing shall protect various stakeholders from receiving and using fake financial statements. For instance, such fake financial statements can lead those stakeholders to making wrong financing and investment decisions that can lead to unknown disastrous consequences.

In order to analyze the collected data statistically, Al- Shawawra \& Al-Hamaydeh (2010) used descriptive statistical methods (arithmetic mean, standard deviation and Mann-Whitney- U Test) and Statistical Package for the Social Sciences (SPSS) program. It was concluded that managing and implementing most of the elements that constitute the framework of the internal audit units efficiently shall lead to improving the efficiency of the audit committees emerging from the board of directors in the Jordanian public joint stock companies

Hamada (2010) conducted a study titled "the role of the audit committees in affecting the efficiency of the creative accounting practices: (A field study)

After the collapse of many major global companies, there was much attention given to proposing new mechanisms that can reduce the practices of manipulation and cheating in the financial reports. The audit committee is considered one of those mechanisms. For instance, such committees are considered responsible for reducing such practices of manipulation and cheating through performing supervisory and control tasks in companies.

The study of Hamada (2010) aimed to identify the activities performed by the audit committees and their roles in affecting the efficiency of the creative accounting practices. In order to achieve the study's objectives, the researcher designed a questionnaire and distributed its forms to a number of external auditors and members of audit committees in Syrian joint stock companies. The questionnaire included the activities that may be performed by the audit committees which may affect the efficiency of the creative accounting practices in companies. The study concluded that there are a group of activities that are performed by the audit committeeswhen performing their tasks- which affect the efficiency of the creative accounting practices in the Syrian joint stock companies.

Lisa et al. (2009) conducted a study titled "the interrelationship between the characteristics of audit committees and cheating in the financial statements".

The study of Lisa et al. (2009) aimed to investigate the relationship between having a neutral audit committee in the facility and the possibility of committing such practices of cheating in the financial statements. For instance, the researchers examined the variables that may affect the possibility of committing such practices of cheating in the financial statements other than the independence of the audit committee. It was concluded that the possibility 
of committing practices of cheating in the financial statements is negatively correlated with the independence of the audit committee and the number of their held meetings. The study concluded that having an independent audit committee can't fully eliminate the possibility of committing a practice of cheating in the financial statements.

\subsection{The Study's Hypotheses}

Ho1: Audit committees do not participate in reducing the liquidity risk levels in Jordanian commercial banks

Ho2: There are no statistically significant differences between the extent of the audit committees' contribution in reducing the liquidity risk levels in Jordanian commercial banks which can be attributed to the auditor's years of experience

Ho3: There are no statistically significant differences between the extent of audit committees' contribution in reducing the liquidity risk levels in Jordanian commercial banks which can be attributed to the auditor's academic qualification

\subsection{The Theoretical Framework}

\subsubsection{The Historical Development of Auditing}

The profession of auditing is considered an ancient profession that has been practiced since the times of the ancient civilizations of the Egyptians, Romans, and Greek. The origins of the profession of auditing go back to the middle Ages. As for the modern meaning of the concept auditing, it goes back to the times of establishing big industrial companies. Auditing went through major developments with the developments of those companies (Al-Matarneh, 2006, p.13).

\subsubsection{Definition of Auditing}

As for the etymology of the word auditing, it should be noted that it is derived from the Latin word (Audire) which means (Listening). That is because the financial statements used to be recited to the auditor. As for the meaning of auditing as a profession, it refers to the process of making a technical and critical check for the facility's documents, books and records. Such check must be free from any form of bias and it should aim to check the validity of the facility's operations and provide an opinion about the fairness of the facility's financial reports relying on the strengths of the internal control system (Juma'ah, 2005, p.6).

Based on the aforementioned definition, auditing includes two main duties:

1) Checking the facility's documents, books and records

2) Delivering the information obtained from the auditing process which is called the final output of the auditing process. Such output is represented in the auditor's report

\subsubsection{Objectives of Auditing}

Saraya (2007, p. 39) believes that the objectives of the auditing process are represented in the following:

1) Auditing is the primary independent and impartial instrument that aims at checking the financial statements of the facility's

2) Auditing provides an objective opinion about the facility's reports, systems and measures that should protect its properties

3) The auditing process conducts an objective, impartial and independent checking for the managerial and economic efficiency of the facility's operations. It conducts a similar check for the extent of those operations' conformity with the facility's objectives.

4) Auditing reports the results of the auditing process to the concerned authorities at the suitable time and in an objective logical form.

\subsubsection{Advantages of Auditing}

The most significant advantages of auditing are represented in the following (Al-Matarneh, 2006, p. 22):

1) Auditing can detect the errors and the practices of manipulation that may be committed by the facility's employees.

2) If the facility's financial records were audited, then that shall enable the facility to obtain loans and debts easily.

3) If the facility's financial records were audited, then the facility can identify the income tax levied on it easily and accurately. 
4) If the facility's financial records were audited, then its price can be easily determined in case it is going to be sold.

5) Having audited financial records can help the facility in settling any dispute that may arise between it and its employees regarding their wages.

6) Having an audited financial records can help the insurance company in determining the amount of compensation to be paid in case the facility incurred damages due to occurrence of any natural disaster (i.e. fire, flood, or etc....).

7) Auditing is considered to be the best method for identifying the degree of the facility's commitment to keeping the records and books in compliance with the international accounting standards (IAS) and the laws and regulations that are applicable in the facility's country.

8) The facility can benefit from the auditor's experience who audit the its records constantly. For instance, the auditor may advise the facility about the faults and weaknesses that may exist in its management or accounting system.

The researcher of the current study believes that the most significant advantages of external auditing is represented in being a system that can inform the facility of its degree of commitment to the codes of the accounting profession (the conceptual framework of financial accounting). Thus, auditing can be considered as being a trustworthy security guard that monitors things closely and reports the commitment of any violation. It should be noted that such guard can't prevent the commitment of any violation. However, knowing about the existence of such a guard shall make people afraid of committing any violation. Thus, when having such a trustworthy guard that people depend on the information he has audited professionally, that shall make the decisions made on the basis of such information successful ones.

\subsubsection{Determinants of Auditing}

Al-Matarneh (2006) \& Persons (2009) believe that the determinant that may affects the strength of the auditing outcomes are represented in the following:

1)- The auditor shall start performing his tasks after the accountant finishes his work. Thus, the auditor does not have adequate information about the information included in the records to be audited and the way these records were prepared. Thus, that means that it is possible to have a skillful practices of manipulation and forgery within these records that are difficult for the auditor to detect even if he exerted major professional efforts.

However the researcher of the current study believes that this determinant is not attributed to a defect in the auditing process itself. For instance, it should be noted that the auditor possess a higher skill level than the accountant because the auditor must attend certain hours of specialized training courses to make him highly efficient. If the auditor did not possess such higher levels of efficiency, then that reflects a lack commitment to the rules of the professional conduct. In other words, not being able to detect the practices of manipulation and forgery within the facility's records doesn't reflects a defect in the auditing process itself. In fact, it reflects an individual fault committed by the auditor himself.

2)- The information included in the books and records may not be sufficient for the auditor to reveal the truth. Thus, sometimes the auditor resorts to searching for additional information obtained from people. However, those people may be involved in the practices of manipulation and forgery. Hence, that means that the audited financial statements do not necessarily reflect an accurate image about the facility's financial situation.

However, the researcher of the current study believes that this is not considered as being a defect. In fact, it's quite the opposite. For instance, if the auditor found that the books and records lack certain information, he must report that through the report he will submit.

3)- The problem related to the reliability of the obtained evidence and clues. For instance, the auditor seeks to obtain them from external sources to enable him to provide an opinion about the fairness of the financial statements. However, such evidence and clues may not by correct. For instance, the auditor may get a confirmation from the customer himself about the amount of money in his account balance that is stated in the books. In such a case, the customer may provide the auditor with an incorrect information. However, the researcher of the current study believes that this point is not logical. To illustrate more, how could a customer confirm an incorrect value representing his account balance! In case the customer committed such an act, then he's giving up his rights and providing information that does not serve his interests!!

4)- Following certain methods and plan when auditing the records and books of a certain facility requires having certain evidence and clues that support the validity of the information mentioned in these records and books. 
Such evidence and clues must be in agreement and consistent with the adopted methods and plan. However, these evidence and clues may not be consistent with the facility's nature and that can prevent the auditor from reaching accurate results. The researcher of the current study believes that such information is incorrect. For instance, one of the requirements for carrying out the auditing process includes the auditor's awareness about the nature of the facility. If the auditor was not aware about the facility's nature, then that doesn't reflect a default in the auditing process itself. In fact, it reflects an individual error committed by the auditor himself.

5)- The auditing process is a sample based process. To be specific, carrying out the auditing process does not mean that the auditor will carry out a comprehensive audit process for the facility's records and financial statements. For instance, the auditor's work is based on selecting random samples chosen from the facility's financial statements to be checked. In other words, auditors do not audit the whole records and financial statements of the facility.

6)- When the auditor finish the auditing tasks assigned to him, he must provide his opinion about the fairness of the financial statements. The auditor usually bases his opinion in such a matter on the evidence and clues that he has collected which should be consistent with the speculated information. However, some evidence and clues may be not be related to the audited element. That means that the audited financial statements will not reflect an accurate image about the facility's financial position. However, the researcher of the current study believes that such determinant is incorrect. For instance, if the auditor was professional and takes the codes of his profession into his consideration and provided an impartial opinion, then the audited financial statements shall reflect the facility's financial situation.

\subsection{Evidence}

Evidence represents the reasonable logical basis of the opinion provided by the auditor about the financial statements he has audited. Evidence also represents the basis of the auditing process and it represents a major part of the rules of field inquiry to be followed by the auditor. For instance, evidence is used by the auditor as a basis for certain decisions he makes. That is because he believes that evidence provides him with a logical wise basis for his speculations and decisions about the fairness and validity of the facility's financial statements (Saraya, 2007, p. 271).

Thus, the auditor must carefully choose the appropriate method(s) for collecting evidence to obtain a reliable evidence. In addition, the auditor must be careful in choosing the source(s) of his evidence. The most significant sources of the auditor's types of evidence include: documents, records, policies, procedures, personal meetings, personal observations, internal control system, and financial analysis.

\subsection{Sufficiency and Appropriateness of the Evidence}

Sufficiency and appropriateness of the audit evidence are both connected with one another. As for the evidence sufficiency, it is considered as a measure for identifying the adequacy, relevancy and appropriateness of the collected evidence. Sufficiency is also an indicator for identifying the extent of the evidence reliability and relatedness. The auditor usually uses his professional experience to evaluate the sufficiency of the collected evidence and make a decision about that. However, such a decision is usually influenced by the following (Al-Tamimi, 2006, p. 105):

1) The amount of money listed in the item of the financial statement: For instance, if the value included in that item referred to a great amount of money in comparison with the other items, then the auditor must seek obtaining an evidence that is more convincing than other ones.

2) The nature of the item of the financial statement, and the risks embedded within that item: For instance, cash assets carry more embedded risks within than the fixed assets.

3) The auditing procedures that shall be adopted

4) Time of carrying out the auditing process and its procedures: Is the auditing taking place during the initial stage (if the auditing was conducted through several stages) or at the end of the year?

The extent of the evidence reliability and credibility depends on the source that the evidence was obtained from. According to Al-Tamimi (2006) and Lai et al. (2005) types of evidence can be arranged in the following order according to their extent of credibility and how convincing they are to the auditor:-

1) The evidence that was obtained by the auditor himself directly. Such kind of evidence is considered more convincing that the information obtained indirectly, such as: counting the cash in the facility's fund or the investment fund. 
2) The evidence obtained directly from external independent sources, such as having a data match between the financial statements and the bank accounts and accounts receivable.

3) The evidence obtained from outside the facility being audited and it is available within the facility, such as: the purchase invoices.

4) The evidence prepared within the facility being audited and the facility possess copies of, such as: the sales bills

It should be noted that the evidence and information that are subjected to internal control are considered more reliable than the ones that aren't subjected to such control. Furthermore, written evidence is considered more reliable than the verbal ones.

\subsubsection{Types of Financial Auditing}

Auditing can be classified into many types. Each type of them can be classified into various sub-types. However, auditing is classified to such types for the purposes of description only. That is because external auditing can't be independent, otherwise it would lose its essence because its performance depends fully on other types of auditing. Auditing can be classified in terms of:

1- Limits

2- Scope of examination

3- Time of conducting auditing

4- Degree of independence

5- Degree of commitment to making portfolio (Jum'ah, 2005; Walker et al., 2011).

\section{The Study's Sample and Population}

The study's population consisted of all the auditor's working in the accounting department in Jordanian commercial banks. Forty (40) questionnaire forms were distributed to the study's respondents who were selected randomly.

\subsection{The Study's Instrument}

The study's questionnaire is shown in the annex of the current study. The researcher of the current study adopted this questionnaire as an instrument for testing the hypotheses of the current study. The questionnaire consisted of two major parts. These two parts are represented in the following:

1)- The first part: It is concerned with the demographic characteristics of the study's respondents. Such characteristics refer to their age, educational qualification, position, major, and years of experience.

2)- The second part: It includes questions that aims at testing the hypotheses of the current study

The researcher of the current study adopted the five point Likert scale in order to answer the study's questions that concern the study's variables. This scale consisted of five points of assessment which are showed below:

\begin{tabular}{llllll}
\hline Response levels & Strongly agree & Agree & Neutral & Disagree & Strongly disagree \\
\hline Points & 5 & 4 & 3 & 2 & 1 \\
\hline
\end{tabular}

Arithmetic means and standard deviations were calculated. There were certain categories set to classify their values. For instance, if the value is (2.33 or below), then it shall be considered low. If the value is within the range of (2.34-3.66), then it shall be considered moderate. However, if the value is ( 3.67 or more), then it shall be considered high. This classification was set based on the following equation:

The highest rate (5) - the lowest rate (1) / the categories' number(3) $=(1.333)$.

\subsection{Statistical Methods}

The data collected in the current study were analyzed through using the Statistical Package for the Social Sciences (SPSS) program. The following statistical methods were used to analyze the collected data:
A)- Cronbach's Alpha test was conducted to test the reliability of the instrument of the current study.
B)- Descriptive statistical methods: Such methods included:
1)- Frequencies 
2)- Percentages

3)- Arithmetic means

4)- Standard deviation

C)- One-Sample-t-test was conducted to test the first hypothesis

D)- ANOVA test: to test the second hypothesis

\subsection{Characteristics of the Study's Sample}

\section{1)- Age}

Table 1. The sample distribution according to their gender

\begin{tabular}{lll}
\hline Age & Frequencies & Percentage $\%$ \\
\hline Less than 30 years & 8 & $20 \%$ \\
$31-$ 40years & 16 & $40 \%$ \\
$40-50$ years & 8 & $20 \%$ \\
50 years or more & 8 & $20 \%$ \\
Total & 40 & $100 \%$ \\
\hline
\end{tabular}

It can be noticed that twenty (20\%) of the respondents' ages are less than thirty (30) years old. Furthermore, forty $(40 \%)$ of the respondents' ages are within the range of $(30-40)$ years old. As for the rest of the respondents, their ages exceed forty (40) years old.

\section{2)- Academic qualifications:}

Table 2. The sample distribution according to their academic qualifications

\begin{tabular}{lll}
\hline Academic qualification & Frequencies & Percentage \% \\
\hline A degree less than the BA degree & - & - \\
BA degree & 32 & $80 \%$ \\
MA degree & 8 & $20 \%$ \\
Ph.D. degree & - & - \\
Total & 40 & $100 \%$ \\
\hline
\end{tabular}

It can be noted that eighty (80) \% of the respondents hold a BA degree, while twenty (20\%) of the respondents hold an MA degree.

\section{3)- Years of experience}

Table 3. The sample distribution according to their years of experience

\begin{tabular}{lll}
\hline Years of experience & Frequencies & Percentage $\%$ \\
\hline Less than 5 years & 16 & $40 \%$ \\
$6-10$ years & 8 & $20 \%$ \\
$11-15$ years & 8 & $20 \%$ \\
More than 15 years & 8 & $20 \%$ \\
Total & 40 & $100 \%$ \\
\hline
\end{tabular}

It can be noted that forty (40\%) of the respondents possess less than five (5) years of experience. In addition, twenty $(20 \%)$ of the respondents possess an experience ranging between (6 to 10) years. As for the rest of the respondents, they possess more than (10) years of experience.

\section{4)- Major}


Table 4. The sample distribution according to their majors

\begin{tabular}{lll}
\hline Major & Frequencies & Percentage \% \\
\hline Accounting & 36 & $90 \%$ \\
Business administration & - & - \\
Banking and financial sciences & 4 & $10 \%$ \\
Others & - & - \\
Total & 40 & $100 \%$ \\
\hline
\end{tabular}

It can be noted that ninety $(90 \%)$ of the respondents possess a degree in the field of accounting. However, ten $(10 \%)$ of the respondents possess a degree in the field of banking and financial sciences

\section{5)- Position}

Table 5. The sample distribution according to their positions

\begin{tabular}{lll}
\hline Position & Frequencies & Percentage $\%$ \\
\hline Financial manager & - & - \\
Internal auditor & 32 & $80 \%$ \\
Accountant & 8 & $20 \%$ \\
Others & - & - \\
Total & 40 & $100 \%$ \\
\hline
\end{tabular}

It can be noted that eighty $(80 \%)$ of the respondents work as internal auditors. However, twenty $(20 \%)$ of the respondents work as accountants.

\section{Results}

Arithmetic means, and standard deviations were used to identify the respondents' attitudes towards the statements of the questionnaire:

Table 6. Arithmetic means, and standard deviations

\begin{tabular}{|c|c|c|c|c|}
\hline & Statements & $\begin{array}{l}\text { Arithmetic } \\
\text { means }\end{array}$ & $\begin{array}{l}\text { Standard } \\
\text { deviations }\end{array}$ & Rank \\
\hline 1 & The committee consists of three members at least & 3.9000 & .54538 & 3 \\
\hline 2 & The committee's members possess the required qualifications in the financial field & 3.9000 & 1.05733 & 4 \\
\hline 3 & The committee's members possess the required experience in the financial field & 4.1000 & .70892 & 6 \\
\hline 4 & $\begin{array}{l}\text { One of the committee's members used to be a bank employee in the bank during the last } \\
\text { fiscal year or the last three ones. }\end{array}$ & 3.5000 & .50637 & 1 \\
\hline 5 & There are members in the bank's committee who hold an executive position & 3.6000 & .92819 & 2 \\
\hline 6 & $\begin{array}{l}\text { The committee monitors the extent of the bank's compliance with the securities act, and the } \\
\text { regulations, instructions and decisions that we reissued by the bank itself. }\end{array}$ & 4.2000 & .75786 & 7 \\
\hline 7 & $\begin{array}{l}\text { The committee examines the periodical reports before being they are sent to the board of } \\
\text { directors and it provides recommendation regarding them. }\end{array}$ & 4.1000 & 1.15025 & 5 \\
\hline 8 & $\begin{array}{l}\text { The committee discusses the matters related to the nomination of an external auditor. It also } \\
\text { makes sure that the nominated external auditor has met all the requirements proposed by the } \\
\text { board. It also make sure that there is nothing that may affect his independency. It investigates } \\
\text { the effect of the other works that he might be doing for the bank on his independency }\end{array}$ & 4.3000 & .46410 & 9 \\
\hline 9 & $\begin{array}{l}\text { The committee investigates all the matters related to the auditor's work, including his notes, } \\
\text { suggestions, and reservations. The committee also monitors the bank's response to them and } \\
\text { it provides the board of directors with recommendations regarding them. }\end{array}$ & 4.7000 & .46410 & 10 \\
\hline 10 & $\begin{array}{l}\text { The committee audits, monitors and assess the bank's systems of financial control, internal } \\
\text { auditing and risk management }\end{array}$ & 4.2000 & .40510 & 8 \\
\hline
\end{tabular}

It is noticed that the respondents' attitudes towards the statements of the questionnaire are considered positive. They are considered so because the arithmetic means of the questionnaire's statements are considered high 
values according to the aforementioned classification.

\subsection{The Instrument's Reliability}

Cronbach's Alpha test was conducted to test the reliability of the instrument of the current study and identify the extent of its reliability. The calculated value is $(0.824)$ which is considered as being an excellent value because it far exceeds the accepted value (0.60).

\subsection{Hypotheses Testing}

\section{The first hypothesis}

Ho1: Audit committees do not participate in reducing the liquidity risk levels in Jordanian commercial banks

Table 8. Results of testing the first hypothesis

\begin{tabular}{llll}
\hline The calculated $t$ value & The tabulated $t$ value & Sig. (Alpha) & Result of the null hypothesis \\
\hline 14.36 & 2.0227 & 0.000 & Rejected \\
\hline
\end{tabular}

One-Sample-t-test was conducted to test the first hypothesis. Based on the table above, it can be noticed that (the calculated $t$ value $=14.36$ ) is considered greater than (the tabulated $t$ value). According to the statistical rules, it is known that the null hypothesis is accepted in case (the calculated $t$ value) is less than (the tabulated $t$ value). It is also known that the null hypothesis is rejected in case (the calculated $t$ value) is greater than (the tabulated $t$ value).Hence, the researcher rejects the null hypothesis (Ho1) and accepts the alternative hypothesis (Ha1). Thus, that means that the audit committees participate in reducing the liquidity risk levels in Jordanian commercial banks

\section{The second hypothesis}

Ho2: There are no statistically significant differences between the extent of the audit committees' contribution in reducing the liquidity risk levels in Jordanian commercial banks which can be attributed to the auditor's years of experience

Table 9. Results of testing the second hypothesis

\begin{tabular}{llll}
\hline The calculated $\mathrm{f}$ value & The tabulated $\mathrm{f}$ value & Sig. (Alpha) & Result of the null hypothesis \\
\hline 11.438 & 2.90 & 0.000 & Rejected \\
\hline
\end{tabular}

AVOVA test was conducted to test the second hypothesis of the current study. Based on the table above, it can be noticed that (the calculated $\mathrm{f}$ value $=11.438$ ) is greater than (the tabulated $\mathrm{f}$ value). According to the rules, the null hypothesis (Ho) shall be accepted in case the calculated $\mathrm{f}$ value is less than the tabulated one. It is also known that the null hypothesis shall be rejected in case the calculated $f$ value is greater than the tabulated one. Thus, the researcher of the current study rejects the null hypothesis (Ho2) and accepts the alternative hypothesis (Ha2). That means that there are statistically significant differences between the extent of audit committees' contribution in reducing the liquidity risk levels in Jordanian commercial banks which can be attributed to the auditor's years of experience.

\section{The third hypothesis}

Ho3: There are no statistically significant differences between the extent of audit committees' contribution in reducing the liquidity risk levels in Jordanian commercial banks which can be attributed to the auditor's academic qualification

Table 10. Results of testing the third hypothesis

\begin{tabular}{llll}
\hline The calculated $\mathrm{f}$ value & The tabulated $\mathrm{f}$ value & Sig. (Alpha) & Result of the null hypothesis \\
\hline 0.114 & 4.09 & 0.737 & Rejected \\
\hline
\end{tabular}

ANOVA test was conducted to test the third hypothesis of the current study. Based on the table above, it can be noticed that the (calculated $\mathrm{f}$ value $=0.114$ ) is less than the tabulated one. According the rules, the null hypothesis shall be accepted in case the calculated value is less than the tabulated value. It is also known that the null 
hypothesis shall be rejected in case the calculated value is greater than the tabulated one. Thus, the researcher of the current study accepts the null hypothesis (Ho3) and rejects the alternative hypothesis (Ha3). That means that there are no statistically significant differences between the extent of audit committees' contribution in reducing the liquidity risk levels in Jordanian commercial banks which can be attributed to the auditor's academic qualification.

\section{Conclusion}

1. Audit committees participate in reducing the liquidity risk levels in the Jordanian commercial banks.

2. There are statistically significant differences between the extent of audit committees' contribution in reducing the liquidity risk levels in Jordanian commercial banks which can be attributed to the auditor's experience

3. There are no statistically significant differences between the extent of audit committees' contribution in reducing the liquidity risk levels in Jordanian commercial banks which can be attributed to the auditor's academic qualification.

\subsection{Recommendations}

1. The researcher of the current study recommended providing more attention to developing the performance of internal auditors in the Jordanian commercial banks. That shall be done in the aim of raising the accuracy and reliability of the financial statements they audit.

2. The researcher of the current study recommended encouraging internal auditors to comply with the principles of accuracy and reliability in their financial statements in Jordanian commercial banks. He also recommended promoting this to be their dominant way of thinking

3. The researcher of the current study recommended developing the internal auditors' performance in using the advanced information systems. That shall be done in the aim of raising the accuracy and reliability of the financial statements they audit in order to reduce the liquidity risk levels.

4. The researcher of the current study recommended conducting more studies about the same matter with applying them in other sectors.

\section{References}

Al- Shawawra, \& Al-Hamaydeh. (2010). The role of the internal audit units in improving the efficiency of the audit committees emerging from the board of directors in the Jordanian public joint stock companies (A field study).

Al- Tamimi, H. (2006). Introduction to auditing from theoretical and practical point of views. The third edition, Amman, Dar Wa'el Publishing and Distribution House.

Al-Matarneh, G. F. (2006). Contemporary auditing from a theoretical point of view. Amman, Dar Al-Masira Publishing and Distribution House.

Al-Sartawi, A. A., Hamdan, A., Mushtahi, S., \& Abu, E. I. (2013). The impact of audit committees in the Jordanian public joint stock companies on the efficiency of profit management. The Journal of Al-Najah University for Research, 27(4).

Al-Soos, E. S. (2012). The extent of the audit committees' efficiency in supporting the internal and external audit mechanisms, The Islamic University.

Juma'ah, A. H. (2005). Introduction to modern auditing, the second edition, Amman, Dar Al-Safa' Publishing and Distribution House.

Lai, K. W., \& Cheuk, L. C. (2005). Audit Report Lag, Audit Partner Rotation and Audit Firm Rotation: Evidence from Australia. Retrieved from http://ssrn.com/abstract=783684

Lisa, A. O., Diana, R., \& Sandra, W. S. (2009). The association between audit committee characteristics, the contracting process and fraudulent financial reporting. American Journal of Business, 24(1), 57.

Persons, O. (2009). Audit Committee Characterstic and earlier Voluntary of disclosure and governance.

Saraya, M. A. (2007). Principles and rules of comprehensive auditing and reviewing (1st ed.). Alexandria, Al-Maktab Al-Jame'I Al-Hadith.

Walker, A., \& Hay, D. (2011). Non-Audit Services and Knowledge Spillovers: An Investigation of the Audit Report Lag. Retrieved from http://ssrn.com/abstract=18528361 


\section{Copyrights}

Copyright for this article is retained by the author(s), with first publication rights granted to the journal.

This is an open-access article distributed under the terms and conditions of the Creative Commons Attribution license (http://creativecommons.org/licenses/by/4.0/). 